\title{
Susceptibility of maize varieties to periods of weed interference in Southern Guinea Savannah Zone of Nigeria
}

\author{
Tanimu, M. U..$^{{ }^{*}}$, Adeosun, J. O. ${ }^{2}$, Tsado, E. K. ${ }^{3}$, Muhammad, A. ${ }^{1}$ and Nura, K. M. ${ }^{4}$ \\ ${ }^{1}$ Crop Science Department, Faculty of Agriculture, Kebbi State University of Science and Technology, Aliero, Kebbi \\ State, Nigeria. \\ ${ }^{2}$ Crop Production Department, Faculty of Agriculture, Federal University Dutsin-ma Katsina State, Nigeria. \\ ${ }^{3}$ Crop Production Department, School of Agriculture and Agricultural Technology, Federal University of Technology \\ Minna, Nigeria. \\ ${ }^{4}$ Crop Production Department, College of Agriculture, Zuru Kebbi State, Nigeria. \\ ${ }^{*}$ Correspondent author. Email: musaumar99@gmail.com
}

Copyright $@ 2017$ Tanimu et al. This article remains permanently open access under the terms of the Creative Commons Attribution License 4.0, which permits unrestricted use, distribution, and reproduction in any medium, provided the original work is properly cited.

Received 8th April, 2017; Accepted 19th May, 2017

\begin{abstract}
The objective of the study was to investigate the susceptibility of maize varieties to periods of weed interference in southern guinea savannah zone of Nigeria. Two Field trials were conducted during the raining seasons of 2011 and 2012 at the Research Farm of the Federal University of Technology Gidan-kwano, Minna in the Southern Guinea Savannah zone of Nigeria. The trials were laid out in split plot design replicated three times. The main plots treatments comprised of four maize varieties namely Oba -98, Sammaz-13, EVDT Y-2000 and 2008-DTMA-Y-STR and sub-plot treatments were ten periods of the weed-interference. Plots were weeded for 3 weeks after sowing (WAS), 6 weeks after sowing (WAS), 9 weeks after sowing (WAS) and 12 weeks after sowing (WAS) and subsequently left weed infested till harvest. Plots were left weed infested for the corresponding periods and subsequently kept weed free until harvest. The combined analysis showed highest plant establishment at 2008-DTMA-Y-STR $75.65 \%$ and the least was Oba-98, 70.04\%; while EVDTY 2000 and Sammaz-13 were observed to record $74.25 \%$ and $73.34 \%$ respectively. In 2011 , (17) major species of weeds were identified on the experimental field. The species were broadly classified into three weed types as Grasses, Broad leaved and Sedges. Higher weed incidence was observed in 2011, while in 2012, the weed incidence was observed to be lower compared to 2011 wet season. The broadleaf species Fleura aestuans, Commelina benghalensis and sedge weeds species, Cyperus esculentus and Cyperus rotundus were observed to have higher incidence in 2012. Combined cumulative weed dry matter progressively increased as weeding was delayed or as plots were kept unweeded while weed dry matter decreased when plots were kept weed free. It is also concluded that the most susceptible of the tested maize varieties in this study were Oba 98 and 2008-DTMA-Y-STR (crop vigour value of 4.02 each), while the most tolerant is EVDTY-2000 (highest crop vigour value of 4.15). Sammaz-13 (crop vigour value of 4.10) is next to EVDTY-2000 in tolerance. Among the varieties tested, 2008-DTMA-Y-STR had the highest crop establishment percentage, and was observed to have the highest average grain yield of $4.00 \mathrm{~T} / \mathrm{ha}$ followed by +EVDT Y-2000 with an average yield of 3.40 T/ha, Oba-98 3.32 T/ha and Sammaz-13 3.27 T/ha. 2008-DTMA-Y-STR and Sammaz-13 varieties are recommended for farmers' use in the study area.
\end{abstract}

Key words: Establishment, guinea savannah, interference, maize, period's susceptibility, unweeded, varieties, weed, weed free.

\section{INTRODUCTION}

Maize (Zea mays L.) production in Nigeria was initially restricted mainly to the forest zone but the production has 
now expanded to the savannah region where it accounts for over $70 \%$ of the production in the country (Uyovbisere et al., (2001). Kassam et al. (2005) attributed the higher production of the crop in the savannah to more favourable production conditions which includes solar radiation intensities, lower night temperature and low incidence of diseases and pests. Maize is a cereal plant that produces grains that can be cooked, roasted, fried, ground, pounded or crushed to prepare various food items like pap, tuwo, gwate, donkunu and a host of others (Abdulrahaman and Kolawole, 2006). All these food types are readily available in various parts of Nigeria among different ethnic groups which are Hausas, Yorubas, Ibos, Ibiras, Ishas, Binis, Efiks and Yalas (Osagie and Eka, 1998).

The major weed of maize in Nothern Nigeria is Striga. It has been reported that in the Nigerian Savannah, weed related yield losses ranging from 65 to $92 \%$ has been recorded (FAO, 2010). Striga causes estimated cereal grain losses of up to N1, 050.00 billion which affects the lives of about 300 million people (IITA 2009).

Hoeing is the cultural method adopted for weed control in cereals of which maize is inclusive in the southern guinea savannah zone. Hoeing is laborious, slow, expensive and only feasible on a small holding (Lagoke, 1988; Adeosun, 1990). Some weeds especially those that have close resemblance with the maize crop at the young stage (Andropogon gayanus) may however escape weeding. These weeds will compete with maize seriously and cause reduction in yield considerably. Hoe weeding is beneficial to the maize crop because it tends to improve aeration in the soil environment. For the hoe weeding to be successful, proper timing and frequency of weeding are necessary.

Weeds pose a problem to the growth, development and yield of maize crop. Like in other crops, weeds compete with maize for sunlight, water, nutrients and space. They cause significant yield losses worldwide with an average of $12.8 \%$ despite weed control applications and $29.2 \%$ in case of no weed control (Ali et al., 2011) The extent of the competition depends on rate of growth of the weeds, their growth habit, their density and time at which they start to grow relative to the crop (Harper, 1988). The density of weeds, relative to that of the crop will clearly have an influence on the degree of onset of competition (Harper, 1988). It is however interesting to note that most studies on the weed interference in maize in the guinea savannah zone of Nigeria have not taken into account the reaction of different varieties to weed competition. The new varieties used for his study are tall growing (especially the hybrid variety) and drought resistant which will enable them to form canopy to suppress the weeds. Hence the need to compare the four maize varieties and investigate their reaction to different weed competition at various periods in this ecological (southern guinea savannah) zone of Nigeria. The objective is to evaluate four maize varieties to periods of weed interference and estimate maize susceptibility.

\section{MATERIALS AND METHODS}

Field trials were conducted during the raining season of 2011 and 2012 at the Research Farm of Federal University of Technology Gidan-kwano, campus Minna (latitude $9^{\circ} 41^{\prime} \mathrm{N}$ and longitude $6^{\circ} 31^{\prime} \mathrm{E}$; $258.5 \mathrm{~m}$ above sea level) in the southern Guinea savanna zone of Nigeria. Climate of Minna is sub humid with mean annual rainfall of about $1284 \mathrm{~mm}$ and a distinct dry season of about 5 months duration occurring from November to March. The mean maximum temperature remains high throughout the year, about $33.5^{\circ} \mathrm{C}$ particularly in March and June (Ojanuga, 2006).

The trial was a Randomised complete block design in a split plot arrangement. The main plots include 4 maize varieties (early, extra early and a late maturing or hybrid) while ten periods of weed interference were sub plots. One set of the interference treatment, plots were kept initially weed free for 3 weeks after sowing (WAS), 6 weeks after sowing (WAS), 9 weeks after sowing (WAS) and 12 weeks after sowing (WAS) and subsequently left weed infested till harvest. In other set of treatments, plots were left weed infested for the corresponding periods and subsequently kept weed free until harvest. Two control treatments were maintained in which one plot weed free while the other plot was left weed infested until harvest. The treatment consisted of two (2) extra early maize varieties, one early variety and one hybrid. The maize varieties tested in this study are: (1) Oba 98. (2) SAMMAZ 13 (Extra early variety). (3) EVDT - Y2000 (Early variety). (4) 2008 DTMA - Y (STR) (Extra early variety).

The field was marked out $\left(1800.00 \mathrm{~m}^{2}\right)$ into split plots and replications. Each split plot $(4 \mathrm{~m} \times 3.75 \mathrm{~m})$ had six ridges. The ridges were spaced at $75 \mathrm{~cm}$. Seeds were sown manually at the rate of 3 seeds per hole along the ridges at intra-row spacing of $50 \mathrm{~cm}$. The plants were thinned to 2 plants per stand at ten days after planting. Weeding using hoe was carried out at 3, 6, 9 and 12 WAS in both years. Basal application of fertilizer in band using NPK 15-15-15 was done at recommended rate of $120 \mathrm{kgN}, 60 \mathrm{kgP}$ and $60 \mathrm{kgK}$ per hectare (Onasanya et al., 2009). This was applied at a distance of about 5 to $8 \mathrm{~cm}$ from the maize plant and below the soil surface at the first application and the urea was applied during the second application. In both cases after the application, the holes were covered with soil to avoid the fertilizer from volatilizing. Fresh weed weight were obtained by taking weed samples at random from $1 \mathrm{~m}^{2}$ quadrat in each plot at 3, 6, 9 and 12 WAS. The weed samples were cleaned free of soil and oven dried at $70^{\circ} \mathrm{C}$ to constant weight and the dry weight was recorded. Cumulative weed dry matter was obtained by adding weights of dried weeds obtained at the respective weeding periods. Major 
Table 1. Physico-chemical properties of soil at the experimental site at a depth of $(0-15 \mathrm{~cm})$ and $(15-30 \mathrm{~cm})$.

\begin{tabular}{lcc}
\hline Soil Properties & $\mathbf{0 - 1 5 c m}$ & $\mathbf{1 5 - 3 0 \mathbf { c m }}$ \\
\hline Physical properties $\left(\mathrm{g} \mathrm{Kg}^{-1}\right)$ & & \\
Sand & 760 & 750 \\
Silt & 110 & 130 \\
Clay & 130 & 120 \\
Textural class & Sandy loam & Sandy Loam \\
& & \\
Chemical Properties & & \\
pH in water $\left(\mathrm{H}_{2} \mathrm{O}\right)$ & 6.7 & 6.5 \\
pH in CaCl & 5.5 & 5.3 \\
Organic carbon (\%) & 2.9 & 3.9 \\
Total Nitrogen & 0.03 & 0.03 \\
Available phosphorus $\left(\mathrm{mg} \mathrm{kg}^{-1}\right)$ & 31.0 & 35.0 \\
& & \\
Exchangeable bases $\left(\mathrm{cmol} \mathrm{kg}^{-1}\right)$ & & \\
Ca & & \\
$\mathrm{Mg}^{2+}$ & 1.61 & 1.10 \\
$\mathrm{~K}^{+}$ & 0.73 & 0.62 \\
$\mathrm{Na}^{+}$ & 0.31 & 0.30 \\
$\mathrm{Exch}^{+}$Acid & 0.07 & 0.08 \\
$\mathrm{ECEC}$ & 0.02 & 0.01 \\
\hline
\end{tabular}

common weeds found on the experimental field for both seasons were recorded. Net plot $(2.25 \mathrm{~m} \times 4 \mathrm{~m})$ from each plot was harvested, threshed, winnowed, weighed and grain yield of maize was calculated on per hectare basis. Data on plant height, crop vigor score was also recorded at 3, 6, 9 and 12WAS. Crop vigour score was assessed visually using a scale of $1-5$, where scale 1 was assigned to plots with completely dead plants, while scale 5 was assigned to the most vigorous plants. Assessment features of the plants used for scoring were height, greenness of the leaves and crop establishment.

\section{Data analysis}

Data collected was subjected to analysis of variance (ANOVA). Means were separated by Duncan Multiple Range Test (DMRT).

\section{RESULTS}

Table 1 shows the physico-chemical properties of soil of the experimental site at depth of 0 to $15 \mathrm{~cm}$ and 15 to 30 $\mathrm{cm}$. The Table showed the different fractions of sand silt and clay with sand having highest value. The textural class of the soil is sandy loam for both depths. The chemical properties showed that it had a fairly alkaline $\mathrm{pH}$, low content of organic carbon, total nitrogen and
ECEC at both depths. On the basis of this fertilizer was applied.

There was high weed infestation during 2011 season than 2012 and conversely the crops performed better in 2012 than 2011. The most prevalent grass weeds include Brachiaria deflexa (Schuman), Digitaria sanguinalli, Rottboellia cochinchinensis and Andropogon gayanus. The prevalent broad leaf weeds were Fleura aestuans (Linn.), Commelina benghalensis(L.), Sida acuta Polak, Tridax procumbens and Calapogonium muconoides. Cyperus esculentus (L.) and C. rotundus (L.) were the only sedges prevalent in the fields. The effect of variety on weed dry matter was only significant in 2012 but not in 2011 (Table 2). During 2011 wet season, the weed biomass was higher than 2012. Weed suppression was shown by weed dry matter of which the varieties were not consistent across the two years of the study. While 2008DTMAYSTR gave the best weed suppression in 2011, EDTY-2000 gave the best weed suppression in 2012. The effect of period of weed interference on cumulative weed dry matter was significant in both years (Table 2). Although weed biomass increased in plots that were initial weed infested from 3 to 12 weeks after sowing and till harvest, this however did not show any statistical significance. Keeping the plot initial weed infested for 9 WAS did not differ significantly from those kept initially weed infested for 12 WAS and till harvest in 2011.

Variety $\mathrm{X}$ period of weed interference was significant on 
Table 2. Effect of variety and period of weed- interference on cumulative weed dry matter production at Gidan-Kwano for 2011 and 2012 Wet seasons.

\begin{tabular}{lccc}
\hline \multirow{2}{*}{ Treatments } & \multicolumn{3}{c}{ Cumulative weed dry (WAS) (T/ha) } \\
\cline { 2 - 4 } & $\mathbf{2 0 1 1}$ & $\mathbf{2 0 1 2}$ & combined \\
\hline Variety & & & \\
Oba-98 & 1.72 & $0.37 \mathrm{~b}$ & 0.88 \\
Sammaz-13 & 1.61 & $0.33 \mathrm{~b}$ & 0.82 \\
EVDTY-2000 & 1.47 & $1.58 \mathrm{a}$ & 081 \\
$2008 D T M A-Y S T R$ & 1.35 & $0.35 \mathrm{~b}$ & 0.69 \\
SE \pm & 0.35 & 0.34 & 0.15 \\
Significance level & $\mathrm{NS}$ & $* \star$ & $\mathrm{NS}$ \\
& & & \\
Period of weed-interference & & & \\
Weed Infested for 3WAS & & & \\
Weed Infested for 6WAS & $0.55 \mathrm{~cd}$ & $0.28 \mathrm{~b}$ & $0.57 \mathrm{~b}$ \\
Weed Infested for 9WAS & $0.62 \mathrm{~cd}$ & $0.44 \mathrm{~b}$ & $0.78 \mathrm{~b}$ \\
Weed Infested for 12WAS & $3.21 \mathrm{a}$ & $0.45 \mathrm{~b}$ & $1.62 \mathrm{a}$ \\
Weed Infested till harvest & $3.39 \mathrm{a}$ & $0.48 \mathrm{~b}$ & $1.72 \mathrm{a}$ \\
Weed free for 3WAS & $3.52 \mathrm{a}$ & $3.36 \mathrm{a}$ & $1.78 \mathrm{a}$ \\
Weed free for 6WAS & $1.53 \mathrm{~b}$ & $0.44 \mathrm{~b}$ & $0.44 \mathrm{~b}$ \\
Weed free for 9WAS & $1.10 \mathrm{bc}$ & $0.39 \mathrm{~b}$ & $0.33 \mathrm{~b}$ \\
Weed free for 12WAS & $0.63 \mathrm{~cd}$ & $0.34 \mathrm{~b}$ & $0.32 \mathrm{~b}$ \\
Weed free till harvest & $0.42 \mathrm{~d}$ & $0.25 \mathrm{~b}$ & $0.22 \mathrm{~b}$ \\
SE \pm & $0.40 \mathrm{~d}$ & $0.18 \mathrm{~b}$ & $0.22 \mathrm{~b}$ \\
Significance level & 0.14 & 0.22 & 0.24 \\
Interaction (VxW) & $* *$ & $* *$ & $* *$ \\
\hline
\end{tabular}

WAS, week after sowing. Means followed by the same letter (s) along the column are not significantly different at $5 \%$ level of probability (DMRT). NS, Not significant. *Significance at $5 \%$ level of probability. ${ }^{* \star}$ Significance at $1 \%$ level of probability.

cumulative weed dry matter (Table 3 ) in all initially weed infested and those of weed free plots during the 2011 wet season. The effect of variety and period of weed interference on maize establishment percentage at harvest during 2011 and 2012 wet seasons ws presented in Table 4. Crop establishment was not affected by variety in 2012 but in 2011. Variety 2008-DTMAYSTR had higher establishment percent than Oba 98 in both years. The effect of variety and period of weed interference on maize crop establishment percentage at harvest during 2011 and 2012 wet seasons was presented in Table 4. Variety did not significantly ( $p>$ 0.05) affect crop establishment in 2012 except in 2011 and the combined. Variety 2008-DTMAYSTR exhibited higher establishment percent than Oba-98 in both years (Table 4). Period of weed interference significantly affected crop establishment percentage in both years (Table 4). The percentage establishment was observed to decrease as plots were kept unweeded after 6WAS, till harvest during 2011 and after 3WAS till harvest in 2012 wet seasons.

The percentage crop establishment was observed to increase to a maximum value when plots were kept weed-free initially from 3WAS till harvest. The crop establishment percentage was higher during 2012 wet season than 2011. However, keeping the crop initially weed infested for 3WAS did not differ significantly in crop establishment percentage from those kept weed free for 12 WAS. There was no significant interaction between the variety and period of weed interference in crop establishment throughout the study (Table 5). In 2011, Crop vigour was not significantly different among the varieties. But in 2012, crop vigour was significantly different between the varieties at 9WAS and at harvest. There was no significant difference $(p>0.05)$ between Sammaz-13 and EVDTY-2000. Period of weed interference significantly affected crop vigour score throughout the period of the study at 9WAS and at harvest (Tables 5). During the 2011, keeping the weed infested up to 6 WAS only was comparable to keeping the crop weed free initially from 6WAS up till harvest (Tables 5). Irrespective of variety used, there was a significant $(p<0.05)$ interaction between the maize varieties and the treatment (periods of weed interference). It was observed at 9 weeks after sowing (9WAS) in 2012 (Table 6). All the varieties showed 
Table 3. Variety X period of weed interference Interaction on cumulative weed dry matter at Gidan-Kwano during 2011 wet season.

\begin{tabular}{|c|c|c|c|c|}
\hline \multirow{2}{*}{ Period of weed-interference } & \multicolumn{4}{|c|}{ Variety (weed dry matter $\mathrm{kg} / \mathrm{ha}$ ) } \\
\hline & Oba98 & Sammaz-13 & EVDT-Y2000 & 2008-DTMA-YSTR \\
\hline Weed Infested for $3 W^{\prime} A^{1}$ & $0.16 \mathrm{e}$ & $0.27 d$ & $0.12 \mathrm{e}$ & $0.24 d$ \\
\hline Weed Infested for 6WAS & $0.21 d$ & $0.29 d$ & $0.24 d$ & $0.37 \mathrm{c}$ \\
\hline Weed Infested for 9WAS & $0.45 b$ & $0.46 \mathrm{~b}$ & $0.48 \mathrm{~b}$ & $0.43 c$ \\
\hline Weed Infested for 12WAS & $0.54 b$ & $0.35 c$ & $0.48 b$ & $0.40 c$ \\
\hline Weed Infested till harvest & $0.55 b$ & $0.43 c$ & $0.60 a$ & $0.36 c$ \\
\hline Weed free for $3 W^{\prime} S^{1}$ & $0.50 \mathrm{~b}$ & $0.42 \mathrm{c}$ & $0.30 d$ & $0.32 c$ \\
\hline Weed free for 6WAS & $0.37 \mathrm{c}$ & $0.42 c$ & $0.30 \mathrm{~d}$ & $0.34 c$ \\
\hline Weed free for 9WAS & $0.50 \mathrm{~b}$ & $0.39 c$ & $0.18 e$ & $0.45 b$ \\
\hline Weed free for 12WAS & $0.27 d$ & $0.18 e$ & $0.23 d$ & $0.33 c$ \\
\hline Weed free till harvest & $0.13 e$ & $0.09 e$ & $0.24 d$ & $0.26 d$ \\
\hline $\mathrm{SE}_{ \pm}$ & & & 0.22 & \\
\hline
\end{tabular}

WAS, week after sowing. Means followed by the same letter (s) along the column are not significantly different at $5 \%$ level of probability (DMRT).

Table 4. Effects of Variety and period of Weed- interference on percentage crop establishment at harvest at Gidan-Kwano for 2011 and 2012 wet seasons.

\begin{tabular}{lccc}
\hline \multirow{2}{*}{ Treatments } & \multicolumn{3}{c}{ Crop establishment at harvest } \\
\cline { 2 - 4 } & $\mathbf{2 0 1 1}$ & $\mathbf{2 0 1 2}$ & combined \\
\hline Variety & & & \\
Oba-98 & $66.92 \mathrm{~b}$ & 73.16 & $70.04 \mathrm{~b}$ \\
Sammaz-13 & $73.26 \mathrm{ab}$ & 73.41 & $73.34 \mathrm{ab}$ \\
EVDTY-2000 & $73.47 \mathrm{ab}$ & 75.02 & $74.25 \mathrm{ab}$ \\
2008DTMA YSTR & $77.54 \mathrm{a}$ & 73.75 & $75.65 \mathrm{a}$ \\
SE \pm & 0.70 & $\mathrm{NS}$ & 0.43 \\
& & & \\
Period of weed interference & & & \\
Initially weed infested for 3WAS & $85.31 \mathrm{a}$ & $86.04 \mathrm{~b}$ & $85.68 \mathrm{a}$ \\
Initially weed infested for 6WAS & $82.90 \mathrm{a}^{2}$ & $74.48 \mathrm{~d}$ & $78.69 \mathrm{bc}$ \\
Initially weed infested for 9WAS & $75.70 \mathrm{ab}$ & $67.54 \mathrm{f}$ & $71.62 \mathrm{de}$ \\
Initially weed infested for 12WAS & $64.24 \mathrm{bc}$ & $60.32 \mathrm{~g}$ & $62.28 \mathrm{f}$ \\
Initially weed infested till harvest & $29.69 \mathrm{~d}$ & $36.95 \mathrm{~h}$ & $33.32 \mathrm{~g}$ \\
Initially weed free for 3WAS & $59.29 \mathrm{c}$ & $71.19 \mathrm{e}$ & $65.24 \mathrm{ef}$ \\
Initially weed free for 6WAS & $73.94 \mathrm{ab}$ & $79.09 \mathrm{c}$ & $76.52 \mathrm{~cd}$ \\
Initially weed free for 9WAS & $84.03 \mathrm{a}$ & $85.05 \mathrm{~b}$ & $84.54 \mathrm{ab}$ \\
Initially weed free for 12WAS & $85.62 \mathrm{a}$ & $86.34 \mathrm{~b}$ & $85.98 \mathrm{a}$ \\
Initially weed free till harvest & $87.24 \mathrm{a}$ & $91.37 \mathrm{a}$ & $89.31 \mathrm{a}$ \\
SE \pm & 4.40 & 1.08 & 2.29 \\
Interaction (V x W) & $\mathrm{NS}{ }^{3}$ & $\mathrm{NS}$ & $\mathrm{NS}$ \\
\hline
\end{tabular}

WAS, week after sowing. Means followed by the same letter (s) / are not significantly different at $5 \%$ level of probability (DMRT). NS, Non significant. - Treatment not applied.

significant difference with the treatment. Considering the responses of the varieties, Oba-98 and EVDT Y-2000 (early variety and drought tolerant) had fairly higher value of crop vigour across the years of 2011 and 2012 while varieties 2008 DTMA-YSTR and Sammaz-13 had the lowest crop vigour among them all. This showed their relative tolerance of weed interference during the growing period. Period of weed interference significantly affected crop vigour at harvest (Table 5). In both years, crop vigour decreases as the plots were kept unweeded and 
Table 5. Effect of Variety and Period of weed- interference on crop vigour score at harvest for 2011 and 2012 Wet seasons Gidan-Kwano.

\begin{tabular}{lccc}
\hline \multirow{2}{*}{ Treatments } & \multicolumn{3}{c}{ Crop vigour score at harvest } \\
\cline { 2 - 4 } & $\mathbf{2 0 1 1}$ & $\mathbf{2 0 1 2}$ & Combine \\
\hline Variety & 4.27 & $3.73 \mathrm{~b}$ & 4.02 \\
Oba-98 & 4.20 & $4.00 \mathrm{a}$ & 4.10 \\
Sammaz-13 & 4.20 & $3.97 \mathrm{a}$ & 4.15 \\
EVDTY-2000 & 4.23 & $3.93 \mathrm{~b}$ & 4.02 \\
2008DTMA-YSTR & $\mathrm{NS}$ & 9.07 & 1.00 \\
SE \pm & & & \\
& & & \\
Period of weed-interference & $4.75 \mathrm{a}$ & $4.2 \mathrm{ab}$ & $4.38 \mathrm{abc}$ \\
Weed Infested for 3WAS & $4.92 \mathrm{a}$ & $4.0 \mathrm{bc}$ & $4.38 \mathrm{abc}$ \\
Weed Infested for 6WAS & $4.25 \mathrm{c}$ & $3.9 \mathrm{bc}$ & $4.13 \mathrm{bc}$ \\
Weed Infested for 9WAS & $3.25 \mathrm{~d}$ & $3.3 \mathrm{de}$ & $3.38 \mathrm{e}$ \\
Weed Infested for 12WAS & $2.33 \mathrm{e}$ & $3.1 \mathrm{e}$ & $2.75 \mathrm{f}$ \\
Weed Infested till harvest & $4.00 \mathrm{e}$ & $3.7 \mathrm{bc}$ & $3.9 \mathrm{bc}$ \\
Weed free for 3WAS & $4.50 \mathrm{ab}$ & $3.8 \mathrm{bc}$ & $4.17 \mathrm{abc}$ \\
Weed free for 6WAS & $4.83 \mathrm{a}$ & $3.9 \mathrm{bc}$ & $4.25 \mathrm{abc}$ \\
Weed free for 9WAS & $4.75 \mathrm{a}$ & $4.1 \mathrm{~b}$ & $4.46 \mathrm{ab}$ \\
Weed free for 12WAS & $4.83 \mathrm{a}$ & $4.5 \mathrm{a}$ & $4.71 \mathrm{a}$ \\
Weed free till harvest & 0.14 & 0.12 & 0.16 \\
SE \pm NS & $\mathrm{NS}$ & $\mathrm{NS}$ & $\mathrm{NS}$ \\
\hline Interaction (VxW) & &
\end{tabular}

WAS, week after sowing. Means followed by the same letter (s) / are not significantly different at $5 \%$ level of probability (DMRT),NS, non significant. - Treatment not applied.

conversely the crop vigour increases as the plots were kept weed free from weed free at 3WAS to weed free till harvest in 2011 and 2012 wet season at the same period.

The effect of variety and period of weed interference on plant height is presented on Table 7. Plant height differed significantly $(p<0.05)$ among the varieties at harvest in 2011 and 2012 (Table 7). Oba-98 and Sammaz-13 consistently had the taller plant than either of EVDTY-2000 or 2008-DTMAYSTR in 2012. Period of weed interference significantly affected plant height in both years. The least plant height was recorded in plots which were not weeded throughout the growing periods for both years. The interaction between the maize varieties and the treatment was not statistically significant ( $p>0.05$ ) (Table 7).

The effect of variety on grain yield was significant only in 2011 (Table 8). Variety 2008-DTMA-YSTR was observed to have the highest grain yield in 2011 with a value of $3.77 \mathrm{t} / \mathrm{ha}$ (Table 8 ) followed by Sammaz-13 (2.71t/ha), next was EVDT Y-2000 (2.57 t/ha) and Oba$98(2.25 \mathrm{t} / \mathrm{ha})$ had the least grain yield value during the 2011 wet season. Although not significant, the yield in 2012 was more than that of 2011.

Period of weed interference significantly affected grain yield in both years and the combine. The grain yield was observed to decrease as plots were kept initially weed infested beyond 3WAS till harvest during 2011 and 2012 wet seasons and the combined. As the plots were initially kept weed free the grain yield was observed to increase from a minimum value of 1.69 to 2.73 to $2.36 \mathrm{t} / \mathrm{ha}$ respectively for 2011,2012 and combined to a maximum value of 3.87 to 6.47 to $5.17 \mathrm{t} /$ ha respectively from 2011 , 2012 and combined hence showing that weeds interfere or deplete nutrients from the soil rendering it unavailable to crop plants.

\section{DISCUSSION}

The prevalent weed species at the experimental site were Cynodon dactylon (L) Pers, Cyperus esculentum (L), Rottboellia cochinchinensis (L), Ageratum conyzoides (Linn). These weeds if not properly controlled could cause serious yield reduction in maize crop (IITA, 2009) hence the low yield obtained in the plots that were weed infested for many weeks (Ali and Sohrab, 2009). Although the varieties were on the field for the same period, obvious differences in their growth and subsequent yields were observed. While hybrid variety 
Table 6. Interaction of Variety and period of Weed interference on crop Vigor at Gidan-Kwano during 2012 wet season.

\begin{tabular}{lcccc}
\hline \multirow{2}{*}{ Period of weed-interference } & \multicolumn{3}{c}{ Variety } \\
\cline { 2 - 4 } & Oba-98 & Sammaz-13 & EVDTY-2000 & 2008-DTMA-YSTR \\
\hline Weed Infested for 3WAS ${ }^{1}$ & $4.33 \mathrm{a}$ & $3.33 \mathrm{abc}$ & $4.67 \mathrm{a}$ & $3.67 \mathrm{ab}$ \\
Weed Infested for 6WAS & $4.00 \mathrm{ab}$ & $4.00 \mathrm{ab}$ & $4.00 \mathrm{ab}$ & $3.33 \mathrm{ab}$ \\
Weed Infested for 9WAS & $4.00 \mathrm{ab}$ & $4.33 \mathrm{a}$ & $4.00 \mathrm{ab}$ & $3.67 \mathrm{ab}$ \\
Weed Infested for 12WAS & $3.33 \mathrm{abc}$ & $4.33 \mathrm{a}$ & $3.00 \mathrm{abc}$ & $3.67 \mathrm{ab}$ \\
Weed Infested for till harvest & $3.33 \mathrm{abc}$ & $4.67 \mathrm{a}$ & $3.00 \mathrm{abc}$ & $3.33 \mathrm{ab}$ \\
Weed free for 3WAS & $3.33 \mathrm{abc}$ & $4.67 \mathrm{a}$ & $4.00 \mathrm{ab}$ & $3.67 \mathrm{ab}$ \\
Weed free for 6WAS & $4.00 \mathrm{ab}$ & $4.00 \mathrm{ab}$ & $4.00 \mathrm{ab}$ & $3.33 \mathrm{abc}$ \\
Weed free for 9WAS & $4.33 \mathrm{a}$ & $4.00 \mathrm{ab}$ & $4.00 \mathrm{ab}$ & $4.00 \mathrm{ab}$ \\
Weed free for 12WAS & $4.00 \mathrm{ab}$ & $3.00 \mathrm{abc}$ & $4.00 \mathrm{ab}$ & $4.00 \mathrm{ab}$ \\
Weed free till harvest & $4.00 \mathrm{ab}$ & $3.67 \mathrm{ab}$ & $5.00 \mathrm{a}$ & $4.67 \mathrm{a}$ \\
SE & & & 0.256 & \\
\hline
\end{tabular}

WAS, week after sowing. Means followed by the same letter (s) / are not significantly different at $5 \%$ level of probability (DMRT).

Table 7. Effects of Variety and period of Weed interference on plant height (cm) at harvest during 2011 and 2012 wet seasons at Gidan-Kwano.

\begin{tabular}{|c|c|c|}
\hline \multirow{2}{*}{ Treatments } & \multicolumn{2}{|c|}{ Plant height (cm) } \\
\hline & 2011 & 2012 \\
\hline \multicolumn{3}{|l|}{ Variety } \\
\hline Oba98 & $171.85 a$ & $189.71 \mathrm{a}$ \\
\hline Sammaz-13 & $168.46 a$ & $185.52 a$ \\
\hline EVDTY-2000 & $127.4 \mathrm{c}$ & $191.46 b$ \\
\hline 2008DTMA-YSTR & $156.35 b$ & $187.95 a$ \\
\hline $\mathrm{SE} \pm$ & 3.86 & 4.05 \\
\hline \multicolumn{3}{|l|}{ Period of weed-interference(W) } \\
\hline Weed Infested for 3 WAS ${ }^{1}$ & $156.54 b c^{2}$ & 195.10abc \\
\hline Weed Infested for 6WAS & $154.84 c$ & 193.18abc \\
\hline Weed Infested for 9WAS & $150.06 c$ & $181.68 c d$ \\
\hline Weed Infested for 12WAS & $149.33 c$ & $175.65 d$ \\
\hline Weed Infested for till harvest & $115.26 \mathrm{~d}$ & $135.40 \mathrm{e}$ \\
\hline Weed free for 3 WAS ${ }^{1}$ & 163.07abc & $188.87 a b c$ \\
\hline Weed free for 6 WAS & $164.65 a b c$ & $200.00 a b$ \\
\hline Weed free for 9WAS & $164.67 a$ & $203.77 a b$ \\
\hline Weed free 12WAS & 171.38ab & 204.15ab \\
\hline Weed free till harvest & $179.34 a$ & $207.95 a b$ \\
\hline $\mathrm{SE} \pm$ & 6.1 & 5.20 \\
\hline Interaction (VxW) & NS & NS \\
\hline
\end{tabular}

WAS, week after sowing. Means followed by the same letter (s) / are not significantly different at $5 \%$ level of probability (DMRT). NS, non significant.

Oba-98 was initially fast growing than other three, the variety 2008-DTMAYSTR was most vigorous until harvest of the other three varieties. This is in conformity with the report of Shinggu et al. (2009) that showed similar effects on some tested maize varieties.
Variety 2008-DTMAYSTR gave the best weed suppression in 2011, EDTY-2000 gave the best weed suppression in 2012, while Oba- 98 produced highest cumulative weed dry matter in 2011 among the other varieties. This might be as a result of the long slender 
Table 8. Effect of Variety and Period of weed- interference on grain yield at Gidan-Kwano, for 2011 and 2012 wet seasons.

\begin{tabular}{|c|c|c|c|}
\hline \multirow{2}{*}{ Treatments } & \multicolumn{3}{|c|}{ Grain yield (T/ha) } \\
\hline & 2011 & 2012 & Combined \\
\hline \multicolumn{4}{|l|}{ Variety } \\
\hline Oba-98 & $2.25 b$ & 4.38 & 3.31 \\
\hline Sammaz-13 & $2.71 b$ & 3.83 & 3.27 \\
\hline EVDT-Y2000 & $2.57 \mathrm{~b}$ & 4.23 & 3.40 \\
\hline 2008DTMA-YSTR & $3.77 a$ & 4.23 & 4.00 \\
\hline $\mathrm{SE} \pm$ & 0.21 & 0.25 & 0.20 \\
\hline \multicolumn{4}{|l|}{ Period of weed-interference } \\
\hline Weed Infested for $3 W^{1}{ }^{1}$ & $3.57 a$ & $5.95 a^{2}$ & $4.76 a$ \\
\hline Weed Infested for 6WAS & $2.51 b c$ & $4.63 \mathrm{bc}$ & $3.57 \mathrm{~cd}$ \\
\hline Weed Infested for 9WAS & $2.40 \mathrm{bc}$ & $3.93 \mathrm{dc}$ & 3.17ed \\
\hline Weed Infested for 12WAS & $1.69 c$ & $2.97 e$ & $2.27 e f$ \\
\hline Weed Infested till harvest & $1.57 \mathrm{c}$ & $1.79 \mathrm{e}$ & $1.74 f$ \\
\hline Weed free for 3WAS & $1.69 c$ & 2.73de & $2.36 \mathrm{ef}$ \\
\hline Weed free for 6 WAS & $2.00 \mathrm{c}$ & $3.53 \mathrm{dc}$ & $3.45 d$ \\
\hline Weed free for 9WAS & $3.59 a$ & $4.25 b c$ & $3.96 \mathrm{bcd}$ \\
\hline Weed free for 12 WAS & $3.67 a$ & $5.41 \mathrm{ab}$ & $4.50 \mathrm{abc}$ \\
\hline Weed free till harvest & $3.87 a$ & $6.47 a$ & $5.17 a$ \\
\hline $\mathrm{SE}_{ \pm}$ & 0.33 & 0.41 & 0.32 \\
\hline Interaction (VxW) & NS & NS & $\mathrm{NS}^{3}$ \\
\hline
\end{tabular}

WAS, week after sowing. Means followed by the same letter (s) / are not significantly different at $5 \%$ level of probability (DMRT). NS, non significant.

leaves of the variety which cannot form canopy to smoother weeds in order to prevent them growing. It is apparent that once the crop was kept weed free for 12 WAS subsequent weed infestation until harvest did not cause any significant reduction in maize grain yield in the four varieties. Contrary to earlier reports (Lagoke et al., 1986), weeds infestation for first 3WAS caused significant reduction in maize grain yield for both seasons and in the combined, even though it did not have adverse effect on crop growth as reflected in crop vigour score, crop height and weed dry matter. The yield depression by weed infestation for 3WAS may be attributed to rapid weed growth and its high infestation within 3WAS during the growing season. This was apparent in the weed cover at 9WAS and beyond. Weed infestation with crop until 12WAS resulted in significantly lower crop vigour and grain yield compared to infestation for 3WAS. This result agrees with those obtained by Carson (2010) and Kunjo (2011) who have similarly reported significant maize yield reduction when weeds were associated with the crop for 6 and 8WAS respectively. Subsequent weed removal until 12WAS did not prevent reduction in grain yield compared with weed infestation until harvest. Weed dry matter was higher during 2011 than 2012. From the results of this study, among the varieties tested 2008DTMAYSTR had the highest crop establishment, while
Sammaz-13, was the most tolerant followed by 2008DTMAYSTR and Oba-98. The most susceptible variety is EVDTY-2000. Weed biomass increased with the initially weed infested from 3 to 12 weeks after sowing and till harvest.

\section{Conclusions and recommendation}

It is therefore recommended to keep the field free of weed from 3WAS when competition between crop and weed commences. In conclusion, 2008-DTMA-Y-STR and EVDTY-2000 maize varieties are also recommended for farmers' use in the study area.

\section{CONFLICT OF INTEREST}

The authors declare that they have no conflict of interest.

\section{REFERENCES}

Abdulrahaman, A. A., \& Kolawole, O. M. (2006). Traditional preparations and uses of maize in Nigeria. Ethnobotanical Leaflets, 2006(1), 23.

Adeosun, J. O. (1990). Valuation of Sowing Date, nitrogen, 
variety and herbicide for the control of Striga hermonthica (Del) Benth in Sorghum (Sorghum bicolour L. Moench). A Thesis submitted to the department of Agronomy, Ahmadu Bello University Zaria.

Ali, K., Munsif, F., Husain, Z., Khan, I., Ahmad, N., Khan, N., \& Shahid, M. (2011). Effect of different weed control methods on weeds and maize grain yield. Pakistan Journal of Weed Science Research, 17(4), 314-315.

Carson, A. G. (2010). Weed competition and control in maize (Zea mays L). Ghana journal of Agricultural Sciences, 9, 161167

FAO (2010). Faosat.

Harper, F. (1988). Principles of Arable Crop Production; Blackwell Science Ltd. Osney Mead, Oxford OX2 OEL. Pp. 202-213

IITA-Maize (2009). Report.

Kassam, A. H., Kowal, J., Dagg, M., \& Harrison, M. N. (2005). Maize in West Africa and its potential in Savanna areas. World Crops, 27(2), 73-78.

Kunjo, I. (2011). An evaluation of the critical period and effect of weed competition on maize (Zea Mays). Phd Thesis, College of Agriculture, Ahmadu Bello University, Zaria, Niggeria, 65p.

Lagoke, S. T. O. (1988). Effect of intra-row spacing, Nitrogen levels and periods of weed interference of transplanted tomato (Lycopersicum esculentum Mill.) in Nigerian Savanna. Samaru Journal of Agricultural Research, 11, 31-42.

Lagoke, S. T. O., Adejonwo, K. O., \& Sinha, T. D. (1986). Herbicide evaluation for Season long weed control in Onion (Allium cepa) on the Nigerian Savanna. In Proceedings $22^{\text {nd }}$ Annual Conference of the Agricultural Society of Nigeria, Ahmadu Bello University Zaria $1^{\text {st }}-3^{\text {rd }}$ September, 1986, Pp. 6-10.
Ojanuga, A. G. (2006). Agroecological Zones of Nigeria Manual. FAO/NSPFS, Federal Ministry of Agriculture and Rural Development, Abuja, Nigeria, 124 pp. In Afolabi, S. G., Adeboye, M. K. A., Lawal, B. A., Adekanmbi, A. A., Yusuf, A. A., \& Tsado, P. A (2014). Evaluation of Some Soils of Minna Southern Guinea Savanna of Nigeria for Arable Crop Production. Nigerian Journal of Agriculture, Food and Environment. 10(4), 6-9.

Onasanya, R. O., Aiyelari, O. P., Onasanya, A., Oikeh, S., Nwilene, F. E., \& Oyelakin, O. O. (2009). Growth and Yield Response of Maize (Zea mays L.) to different rates of Nitrogen and Phosphorus fertilizers in Southern Nigeria. World Journal of Agricultural Sciences, 5(4), 400-407.

Osagie, A. U., \& Eka, O. U. (Eds) (1998). Nutritional Quality of Plant Foods. Post-harvest Research unit, University of Benin, Benin Pp. 34-41.

Shinggu, C. P., Dadari, S. A., Shebayan, S. A. Y., Adekpe, D. I., \& Ishaya, D. B. (2009). Effects of Variety crop arrangement and period of weed interference on the performance of maize grown in mixture in Northern Guinea Savannah of Nigeria. Department of Agronomy, Faculty of Agriculture, Ahmadu Bello University, Zaria, Nigeria, p.48.

Uyovbisere, E. O., Elemo, K. A., \& Tarfa, B. D. (2001). Effect of locust bean (Parkia biglobosa) and neem (Azadiracta indica) on soil fertility and productivity of early maize in savannah alfisol, Pp.185-194. In Badu- Aparaku, B., Fakorede, M.A.B., Quedraogo, M. and R. J. Carsky, R.J (eds). Impact Challenges and prospects of Maize Research and development in West and central Africa. Proceedings of a Regional Maize Workshop, IITA-Cotonou Benin Republic, 4-7 May 1999.WECAMAN/IITA. 